\title{
Strengthening the Effectiveness of Ideological and Political Education in Colleges and Universities, and Striving to Improve the Sense of Acquisition of College Students
}

\author{
Minghui Chen \\ Yunnan Normal University \\ Kunming, China 650000
}

\begin{abstract}
With the improvement of college students' sense of acquisition as the core, the Ministry of Education of China carried out the special work for the teaching quality of ideological and political theory courses in colleges and universities in 2017, and achieved staged results. The sense of acquisition of college students has become an important indicator for evaluation of the teaching effect of ideological and political theory courses in colleges and universities. To improve the sense of acquisition of college students in ideological and political theory courses, we must work hard on the affinity, pertinence and effectiveness of teaching. In combination with the teaching research and practice over the years, the author explores the effective ways to enhance the teaching effectiveness of ideological and political courses in colleges and universities and to improve the sense of acquisition for ideological and political theory courses.
\end{abstract}

Keywords-ideological and political theory course; sense of acquisition; effectiveness

\section{INTRODUCTION}

General Secretary Xi Jinping emphasized at the National Conference on Ideological and Political Work in Colleges and Universities that the teaching of ideological and political theory courses (hereinafter referred to as "Ideological and Political" courses) should be strengthened in the improvement, to enhance the affinity and pertinence of ideological and political education and meet the needs and expectation of students for growth and development. And expectation" [1]. In 2017, the Ministry of Education of China carried out the special work of teaching quality in the dimension of enhancing the quality of "Ideological and Political" course, with the improvement of the sense of acquisition as the core, and achieved stage results; the sense of acquisition of college students has become an important indicator for evaluation of the teaching effect of ideological and political courses. This standard provides a goal and direction for improving the quality of the "Ideological and Political" course in colleges and universities, which requires us to work hard on the affinity, pertinence and effectiveness of teaching. Combining with the personal teaching research and practice, the author has carried out targeted attempt and explorations on the ways to improve the effectiveness of the "Ideological and Political" course from the following five aspects.

\section{FIRST TO CHANGE THE TEACHING CONCEPT, AND ESTABLISH A CORRECT EDUCATIONAL CONCEPT}

Change of the concept of teaching is the forerunner to achieve quality education, and the correctness of the teaching concept directly affects the effectiveness of the curriculum. The teachers of "Ideological and Political" course should put the concept of "talent cultivation as the foundation and moral education as the first" in the first place, and this is the functional and natural principle of the college students' ideological and political education. The teachers of "Ideological and Political" course should establish the "people-oriented" teaching concept, which includes three meanings: first, the concept of "people-oriented care", that is teachers should follow students' conditions, respect students, understand students, concern students, care for students, help students, and are based on students and serve students, which is the targeted way to enhance the sense of acquisition in the "Ideological and Political" course; second, to respect the concept of student for subjectivity, respect their subjective consciousness, pay attention to their independent spirit, make dialogue, discuss issues and exchange ideas with them, fully mobilize their enthusiasm and internal motivation of learning; third, the concept of "teaching students according to their aptitude", that is teachers should carry out different curriculum design according to the characteristics of different teaching groups. For students of science, they should pay more attention to their thinking characteristics and acceptance of the curriculum, with more emphasis on teaching of common sense content and knowledge connotation; for students of liberal arts, they should focus on the enhancement of the teaching of rationality, emphasize indepth knowledge and extension of the connotation; for students of sports and art, the curriculum setting is not single or theoretical, but they should adopt a wide range of teaching methods. 


\section{TO FOCUS ON THE OPTIMIZATION OF TEACHING} DESIGN, AND ESTABLISH A REASONABLE TEACHING SYSTEM

For improvement of the acquisition sense for "Ideological and Political" course, the key is to obtain the recognition of students, and the Critical point is to effectively transform the textbook system into a teaching system. For the transformation of textbook system into a teaching system, we must emphasize the transformation of the textbook advantage into the teaching advantage, and then change it into teaching effectiveness. How to achieve these two transformations depends on the leading role of teachers. Teachers must establish systematic thinking, overall thinking and innovative ideas; in the teaching process, first fully understand the textbooks, follow the logical structure and main content of textbooks for the teaching content. Take the content first, the theory as the base, highlight the key points, grasp the difficulties, and analyze the hot points. Understanding students is the key, so teachers should make design of teaching content in combination with the actual teaching construction content for students and according to students' practical problems and he hot issues they concern, to resolve doubts and problems for college student; keeping up with the situation is a magic key, and keeping pace with the times is the theoretical quality of Marxism. Teachers must always stand in the development frontier of the times to build the teaching content, the teaching content should reflect the party's theoretical innovation achievements and the hot issues of social concern in a timely manner; following its conditions is the basic, teachers should organize targeted teaching content in their lectures in combination with the different characteristics of the institutions and the special conditions of different majors, for example, the normal schools should instruct their students' historical responsibility and professional responsibility in combination with the real education in China to guide them to base themselves on education business, love teaching profession, set up a model of virtue for others, and establish the ideal of contributing to China's education, to infect them by love. Marx pointed out: "emotion and enthusiasm are the essential strengths for people to pursue their objects."[2] Lenin also stressed: "Without 'human's feeling', there is never and may not be human's pursuit for the truth." [3] For "Ideological and Political" course teaching and reform, we should focus on the fundamental tasks of morality and nurturing, combine rational cognition and perceptual touch, pay attention to the integration of emotion and reason and of feeling and justice, influence students with positive emotions, warm students and sooth their souls with positive energy.

\section{TO TAKE THE InNOVATIVE TEACHING ModE AS THE STARTING POINT, AND EXPLORE THE EFFECTIVE TEACHING METHODS}

The teaching characteristics at the college stage are "teaching must have a certain methods, but instructions have no fixed methods", and we must "master the effective methods." The content of the "Ideological and Political" course is very rich and involves many fields, so the teaching method may be flexible and diversed. This requires teachers to have a strong ability to master teaching materials, seriously study the contents of teaching, actively explore teaching models, and achieve the good interaction between "teaching" and "learning", realize the organic combination of "instruction" and "guidance", change "injective" teaching into "interactive" and "heuristic" teaching, truly embody the subjective status of students and achieve the effectiveness of teaching. Teacher should adhere to the "four combinations", adhere to the combination of classroom teaching and afterschool supplementary learning, adopt different teaching methods in the teaching according to different teaching textbooks and different receiving groups, and can use a mixed type of diversified teaching methods, such as heuristic teaching, discussion-based teaching, case-based teaching, lecture-based teaching, thematic teaching, MOOC, etc., guide and organize students to carry out extended reading after class, do well self-study tasks of teaching and tutoring platform, advocate students to making a practice in social activities, adhere to the combination of theoretical teaching and social practice, guide students to participate in social practice and make them really understand the relevant knowledge in the textbooks through practice, and also use the assessment of practices to test the students' ability of "integration of knowledge and practice", and take it as the main reference for students' curriculum evaluation. We should adhere to the combination of traditional teaching and modern teaching; traditional teaching methods and modern teaching methods have their different advantages, and they supplement each other. On the one hand, teachers should adhere to traditional teaching methods, such as writing teaching plans, teaching schemes, teaching cases, etc.; on the other hand, they should actively study and research modern teaching methods, give full play to the technological advantages of multimedia and the richness and promptness of information resources. The characteristics of timeliness; by combination of dynamic and static, education and fun, enhance the persuasiveness and appeal of teaching, deepen students' understanding, stimulate students' interest in learning, and enhance the effectiveness of teaching. Combining the dominant education with the recessive education, for the limited moral education in schools, we can learn from the American concept of "character education", integrate social resources, make moral education run through the environment and process of students' growth, and practically implement the effectiveness of the "Ideological and Political" course, that is "both virtual and real, both edged and sharp, both passionate and righteous, both delight and relish", so as to make students gain from their learning, use their learning and make their learning worth.

\section{TO TAKE THE REFORM ASSESSMENT METHOD AS A GUARANTEE, BUILD A REASONABLE EVALUATION SYSTEM}

The education and teaching of the "Ideological and Political" course is the main channel and main front of the ideological and political work in Chinese colleges and universities, therefore, it is impossible to objectively and truly examine and evaluate the students' learning effects simply by a test paper and students' daily grades, or to examine their theoretical level and culture, and even it is more difficult to testify their ideological and political awareness, value orientation and inner beliefs. Teachers 
should build a long-term diversified and comprehensive mechanism of assessment from the perspective of "knowledge, passion, intention, and behavior" on the basis of multi-faceted, multi-angle and multi-form examinations, to give students objective and fair judgment, which is also an important way to test the effectiveness of the "Ideological and Political" course. First of all, we should change the concept of assessment. The traditional concept of assessment attaches importance to the assessment of knowledge theory but ignores the evaluation of students' internal acceptance and the intensity of practice transformation, so the situation of "excited in the class for a while, and numb after class for a lifetime" often appears, which is actually the failure of teaching. We should pay attention to the combination of theoretical assessment and practical assessment, more attention to the practice assessment, and through this assessment, we guide students to truly transform their knowledge into their ideas and good behavior. Second, refine the content of the assessment. According to the characteristics of the curriculum, adhere to the combination of theoretical assessment and practical assessment, and of the usual assessment and the final assessment, of self-evaluation and teachers' assessment, to set up multi-level, multi-angle and all-round assessment content. Third, establish a longterm effective assessment mechanism and integrate the relevant resources, for example, together with student work organizations, counselors, parents, and classmates, establish moral education files of college students, examine students' compliance with laws and regulations, learning and living conditions, as well as their ideology and morality, thus make a comprehensive assessment, and further give a objective and reasonable evaluation.

\section{WITH THE IMPROVEMENT OF TEACHERS’ PERSONAL QuALITIES AS THE KEY, TO CREATE A TEAM OF TEACHERS WITH PROFESSIONAL EXCELLENCE AND MORAL INTEGRITY}

General Secretary $\mathrm{Xi}$ Jinping pointed out in his investigation on the Peking University on May 2, 2018 that the teachers of the "Ideological and Political" course in colleges and universities shoulder the task of Marxist education and teaching and burden the political mission of preaching the latest achievements of Marxist theory, so they should be the main force of studying and interpreting $\mathrm{Xi}$ Jinping's socialist ideology with Chinese characteristics in the new era. It can be seen that the teachers of the "Ideological and Political" course in colleges and universities have great responsibilities and arduous task. Teachers must first strengthen themselves, and the educator must first discipline himself. As a learner, researcher and communicator of Marxist theory in colleges and universities, the teachers of "Ideological and Political" course in colleges and universities should take a high sense of responsibility and mission, learn and implement the latest achievements of Marxist Chineseization theory, actively put the spirit of the 19th National Congress of the Communist Party of China into the teaching materials and through the classroom teaching, put it into brain work, and further strengthen the ideological and political work of colleges and universities in the process of learning and propagating and implementation, publicize new achievements in the form of "popularization"; to enhance the value recognition of college students with "sense of identity" as the concept; to realize the integration of knowledge and practice in education, guided by "sense of integration"; to further enrich and improve the evaluation system of "Ideological and Political" teaching quality, with the "sense of acquisition" as an indicator; consciously make a deep integration of the political function orientation of the curriculum with the rational needs of the students for growth and development; realize the organic unity of the ideological goals and the educational goals of the curriculum, and enhance the sense of acquisition of students for "Ideological and Political" courses.

\section{CONCLUSION}

The Enhancement of the sense of acquisition is an important goal for reform of the "Ideological and Political" course, and it is also the touchstone for testing the quality of the course. We must follow the rules of ideological and political work, the rules of teaching and educating students, and the law of student growth, with change of the concept of teaching as the guide, optimization of teaching design as the emphasis, innovation of teaching mode as the starting point, reform of assessment method as the guarantee, improvement of teachers' individual quality as the key, to perseverely improve the quality and level of the "Ideological and Political" course in colleges and universities, to enhance the affinity, pertinence and effectiveness of teaching, and to effectively strengthen the college students' sense of acquisition of "Ideological and Political" course.

\section{REFERENCES}

[1] Xi Jinping emphasized at the National Conference on Ideological and Political Work in Colleges and Universities: do well ideological and political work through the whole process of education and teaching to create a new situation for the development of higher education in China [N]. People's Daily, 2016-12-09.

[2] The Complete Works of Marx and Engels, Volume 42 [M]. Beijing People's Publishing House, 1979: 169.

[3] The Complete Works of Lenin, Volume 25 [M]. Beijing: People's Publishing House, 1988: 117. 